\title{
Rimsulfuron Tank Mixed with Flumioxazin, Pendimethalin, or Oryzalin for Control of Broadleaf Weeds in Citrus
}

\author{
Amit J. Jhala ${ }^{1,3}$, Analiza H.M. Ramirez ${ }^{2}$, and Megh Singh ${ }^{2}$
}

ADDITIONAL INDEX WORDs. broadleaf weeds, broad-spectrum, grass weeds, percent control, preemergence, postemergence

SUMMARY. Herbicides are usually applied multiple times by growers for season long weed control in Florida citrus (Citrus sp.). Rimsulfuron, a sulfonylurea herbicide has been recently registered for control of certain grasses and broadleaf weeds in citrus. To increase the weed control spectrum and reduce application cost, citrus growers often prefer to tank mix herbicides. Field experiments were conducted in 2010 and 2011 in citrus groves in central Florida to evaluate weed control efficacy and crop safety of rimsulfuron applied alone or in tank mixes with flumioxazin, pendimethalin, or oryzalin. Herbicides were applied sequentially in spring and fall in both years on the same experimental plot. Results suggested that rimsulfuron applied alone controlled $>\mathbf{8 0} \%$ broadleaf and grass weeds up to 30 days after treatment (DAT) and was comparable to tank mixing rimsulfuron with pendimethalin or oryzalin; however, control was reduced beyond 30 DAT. Rimsulfuron tank mixed with flumioxazin was the most effective treatment at 30 and 60 DAT that provided, respectively, $\geq 88 \%$ and $>75 \%$, control of broadleaf weeds including brazil pusley (Richardia brasiliensis), dog fennel (Eupatorium capillifolium), common ragweed (Ambrosia artemisiifolia), cotton weed (Froelichia floridana), and virginia pepperweed (Virginia virginicum) compared with other treatments. Control of natalgrass (Melinis repens) was higher in all tank mix treatments compared with rimsulfuron applied alone with no difference among tank mix partners. Rimsulfuron tank mixed with pendimethalin or oryzalin had no advantage over rimsulfuron applied alone for control of broadleaf weeds. Among sequential applications, weed control was better after fall herbicide application (August) compared with spring (April) because of residual activity of fall applied herbicides. Rimsulfuron tank mixed with flumioxazin will provide citrus growers with an additional weed control option.

$\mathrm{F}$ lorida is the largest producer of citrus with production of more than $60 \%$ of the total citrus produced in the United States [U.S. Department of Agriculture (USDA), 2010]. In 2011, citrus was grown on more than 500,000 acres with the production of 7,427,000 tons in Florida (USDA, 2012). Weed management is an important horticultural operation in citrus production practices. Weeds are highly competitive with citrus trees under the growing conditions of central Florida because of frequent rainfall, high temperature, and humid weather (Sharma and Singh, 2007). Weed control in Florida citrus relies heavily on herbicides. Herbicides are applied as a uniform broadcast application to the grove floor or as a uniform band

\footnotetext{
${ }^{1}$ Department of Agronomy and Horticulture, University of Nebraska-Lincoln, Lincoln, NE 68583-0915

${ }^{2}$ Citrus Research and Education Center, Institute of Food and Agricultural Sciences, University of Florida, 700 Experiment Station Road, Lake Alfred, FL 33850-2299

${ }^{3}$ Corresponding author. E mail: amit.jhala@unl.edu.
}

application directed at the base of the tree trunk (Singh and Singh, 2004).

Several preemergence and postemergence herbicides are registered for weed control in Florida citrus (Futch and Singh, 2012). Pendimethalin (Prowl $\mathrm{H}_{2} \mathrm{O}^{\text {TM }}$; BASF Corp., Research Triangle Park, NC) and oryzalin (Surflan ${ }^{\circledR}$; United Phosphorus, King of Prussia, PA) are commonly used soil-applied herbicides for control of many annual weeds and certain broadleaf weeds in citrus. Rimsulfuron (Solida ${ }^{\mathrm{TM}}$; Cheminova, Research Triangle Park, NC) is a sulfonylurea herbicide that was registered in 2010 for preemergence and postemergence control of certain grasses and broadleaf weeds in citrus, pome fruit (Maleae), tree nut, stone fruit (Prunus sp.), and grapes (Vitis vinifera) that have been established for at least one full growing season (Cheminova, 2010).

Rimsulfuron is also registered for weed control in several annual crops including corn (Zea mays), potato (Solanum tuberosum), and tomato (Solanum lycopersicum) (Senseman, 2007; Tonks and Eberlein, 2001). It inhibits branched-chain amino acid production in susceptible weeds by inhibition of the enzyme acetolactate synthase (ALS) or acetohydroxy acid synthase. It moves primarily in the phloem with limited mobility in the xylem. Like several sulfonylurea herbicides, rimsulfuron requires an adjuvant for effective weed control (Green and Green, 1993). The initial symptoms of rimsulfuron activity are observed in the meristematic tissues of treated plants. For broadcast application, the recommended rate of rimsulfuron is $4 \mathrm{oz} /$ acre per year; however, when applied as a banded treatment (application of herbicides only covering an area of 3 to $4 \mathrm{ft}$ on each side of the tree in a strip), it may be applied twice per year with a minimum 30-d interval between applications (Cheminova, 2010). Rimsulfuron degrades rapidly in the soil predominantly via chemical pathways. The half-life in laboratory studies is $\approx 20 \mathrm{~d}$ under both aerobic and anaerobic conditions in a sandy loam soil (Schneiders et al., 1993).

A study reported that rimsulfuron applied postemergence provided inconsistent weed control in potato (Eberlein et al., 1994); however, tank mixing with other herbicides such as metribuzin or pendimethalin improved weed control (Hutchinson, 2007). Hutchinson et al. (2005) reported that late-season common lambsquarters (Chenopodium album) control by rimsulfuron applied PRE alone in potatoes has been less than

\begin{tabular}{llll}
\hline $\begin{array}{l}\text { Units } \\
\begin{array}{l}\text { To convert U.S. to SI, } \\
\text { multiply by }\end{array}\end{array}$ & U.S. unit & SI unit & $\begin{array}{l}\text { To convert SI to U.S., } \\
\text { multiply by }\end{array}$ \\
\hline 0.4047 & $\mathrm{acre}(\mathrm{s})$ & $\mathrm{ha}$ & 2.4711 \\
0.3048 & $\mathrm{ft}$ & $\mathrm{m}$ & 3.2808 \\
9.3540 & $\mathrm{gal} / \mathrm{acre}$ & $\mathrm{L} \cdot \mathrm{ha}^{-1}$ & 0.1069 \\
1.1209 & $\mathrm{lb} / \mathrm{acre}$ & $\mathrm{kg} \cdot \mathrm{ha}^{-1}$ & 0.8922 \\
0.0701 & $\mathrm{oz} / \mathrm{acre}$ & $\mathrm{kg} \cdot \mathrm{ha}^{-1}$ & 14.2749 \\
6.8948 & $\mathrm{psi}$ & $\mathrm{kPa}$ & 0.1450 \\
50.9323 & $\mathrm{pt} / 100 \mathrm{ft}^{2}$ & $\mathrm{~mL} \cdot \mathrm{m}^{-2}$ & 0.0196
\end{tabular}


80\%; however, Wilson et al. (2002) reported control of broadleaf weeds including redroot pigweed (Amaranthus retroflexus) by rimsulfuron plus $S$ metolachlor was $99 \%$ to $100 \%$ in potato. Ivany (2002) reported that rimsulfuron tank mixed with metribuzin gave 99\% control of wild radish (Raphanus raphanistrum) and $85 \%$ control of corn spurry (Spergula arvensis) in potato.

Flumioxazin (Chateau ${ }^{\circledR}$; Valent USA Corp., Walnut Creek, CA) is an $\mathrm{N}$-phenylphtalimide herbicide that is registered in several states of the United States for weed control in numerous crops and non-cropland situations (Valent USA, 2005). Flumioxazin is not registered in citrus, but currently being evaluated for weed control and crop safety. It can be absorbed by root or foliage of treated plants and it inhibits protoporphyrinogen oxidase (Dayan and Duke, 1997). Flumioxazin has both preemergence and postemergence activity; therefore, when it is applied to soil, most susceptible weed seeds and seedlings will die as they begin to emerge; whereas foliar contact to susceptible plants results in a rapid desiccation followed by necrosis (Hutchinson, 2007). A study for weed control in gladiolus (Gladiolus sp.) reported that flumioxazin provided $78 \%$ control of common ragweed, yellow nutsedge (Cyperus esculantus), and foxtail species (Setaria sp.) at 12 weeks after treatment (Richardson and Zandstra, 2006). Several studies reported that flumioxazin efficacy could be improved by tank mixing herbicides with different mode of action. For example, flumioxazin applied alone as a preemergence resulted in poor annual grass control that was improved by tank mixtures (Askew et al., 1999; Burke et al., 2002; Kelly et al., 2006).

Citrus growers use herbicide tank mixtures depending upon type and density of weed species present in the grove. By tank mixing herbicides, the weed control spectrum can be increased (Hutchinson, 2007; Jhala and Hanson, 2011). For example, saflufenacil, a contact herbicide for broadleaf weed control, was tank mixed with glyphosate and pendimethalin to provide broad-spectrum weed control in Florida citrus (Singh et al., 2011). To develop weed control programs that includes rimsulfuron, more information is required to understand compatibility of rimsulfuron with herbicides commonly used in citrus and new herbicides that are under evaluation. Therefore, the objective of this research was to compare weed control efficacy of rimsulfuron applied alone and in tank mixtures with flumioxazin, pendimethalin, or oryzalin.

\section{Materials and methods}

Field experiments were conducted in a citrus grove near Haines City, FL, in 2010 and near Winter Garden, FL, in 2011 to compare weed control efficacy of rimsulfuron applied alone or in tank mixes. The experimental soil was a typical well-drained, fine Candler sand (Hyperthermic, uncoated Typic Quartzipsamments) and representative of the majority of Florida's citrus growing region. The soil had $\mathrm{pH}$ of $6.4,89 \%$ sand, $7 \%$ silt, $5 \%$ clay, and $<0.5 \%$ organic matter content. The experiments were conducted in randomized complete block design with four replicates. The plot size was $40 \times 10 \mathrm{ft}$ covering five citrus trees per plot. Treatments included rimsulfuron [Solida ${ }^{\mathrm{TM}}$ or Matrix ${ }^{\circledR}$ FNV (E.I. Du Pont de Nemours and Co., Wilmington, DE)] applied alone at $\mathrm{loz} /$ acre; rimsulfuron (Sol$\mathrm{ida}^{\mathrm{TM}}$ ) at $1 \mathrm{oz} /$ acre applied in a tank mix with flumioxazin at $0.255 \mathrm{lb} /$ acre, pendimethalin at $1 \mathrm{lb} /$ acre or oryzalin at $2 \mathrm{lb} /$ acre (Table 1). An untreated control was included for comparison. All herbicide treatments were mixed with a nonionic surfactant (Induce ${ }^{\circledR}$; Helena Chemical Co., Collierville, TN) at $0.25 \% \mathrm{v} / \mathrm{v}$.

Herbicide treatments were applied on 14 Apr. 2010 and 7 Apr. 2011 at Haines City and Winter Garden, respectively, using a tractormounted computerized boom sprayer fitted with 8002 Teejet nozzles (Spraying System Co., Wheaton, IL) and an off-centered OC-4 flat spray tip delivering $20 \mathrm{gal} / \mathrm{acre}$ spray volume at 30 psi. Citrus species was sweet orange (Citrus sinensis) 'Valencia' and 'Navel' at Winter Garden and Haines City, respectively. The citrus trees were two years old at the time of the herbicide spray. Visual percent control of grass and broadleaf weeds were recorded at $15,30,60$, and 90 DAT on a scale $0 \%$ to $100 \%$, where $0 \%$ is no control and $100 \%$ is complete control of weeds at the time of observation compared with untreated control. Phytotoxicity of the herbicide treatments on citrus trees was also evaluated at $15,30,60$, and 90 DAT based on a $0 \%$ to $100 \%$ scale, where $0 \%$ is no injury and $100 \%$ is complete death of the tree.

The experimental site was infested with several weeds at $90 \mathrm{~d}$, therefore, the site was sprayed with glyphosate at $2 \mathrm{qt} /$ acre on 15 July 2010 at Haines City site and on 8 July 2011 at Winter Garden site. The trial was repeated with the same herbicide treatments on the same plots/ randomization (referred to as Expt. 2). The repeat application of same herbicide treatments was made on 25 Aug. 2010 and 23 Aug. 2011 at Haines City and Winter Garden, respectively. Visual percent control of grass and broadleaf weeds and crop safely data were recorded at 15,30 , and $60 \mathrm{DAT}$ as per the procedures explained above.

Statistical analysis. All data were subjected to analysis of variance (ANOVA) using statistical analysis software (version 9.2; SAS Institute, Cary, NC) to test for treatment effects and possible interactions. Normality, homogeneity of variance, and interactions of treatments and years (2010 and 2011) were tested. Interaction among years was nonsignificant; therefore, data were pooled and combined data were presented. Weed density data were arcsine square root transformed before analysis; however, nontransformed means were presented with mean separation based on transformed values. When the ANOVA indicated treatment effects were significant, means were separated at $P \leq 0.05$ and adjusted with Fisher's protected least significant difference test.

\section{Results and discussion}

Data analysis suggested that there was a nonsignificant difference for weed control and crop safety data among two years (2010 and 2011); therefore, data were pooled and combined data were presented. Herbicide treatments were applied twice in both the years, so results were discussed separately for April treatment (Expt. 1) followed by August treatment (Expt. 2).

EXPERIMENT 1. Common broadleaf weed species infesting experimental sites in Haines City (2010) and Winter Garden (2011) were brazil pusley, dog fennel, common ragweed, 
and virginia pepperweed. Results suggested that all treatments provided significantly higher weed control compared with the untreated control at 15 , 30,60 , and 90 DAT (Tables 1 and 2). Control of all broadleaf weeds was $\geq 97 \%$ at 15 DAT revealing that rimsulfuron (Solida ${ }^{\mathrm{TM}}$ ) applied alone was as effective as rimsulfuron (Solida ${ }^{\mathrm{TM}}$ ) tank mixed treatments (Table 1). Similarly, all herbicide treatments were equally effective for control $(\geq 82 \%)$ of common ragweed at 30 DAT; however, control of dog fennel and virginia pepperweed was higher in rimsulfuron (Solida ${ }^{\mathrm{TM}}$ ) tank mixed with flumioxazin compared with rimsulfuron (Solida ${ }^{\mathrm{TM}}$ ) applied alone (Table 1).
All tank mixed treatments were usually equally effective for control of broadleaf weeds at 30 DAT; however, a difference was observed at later in the season $(\geq 60$ DAT). For example, rimsulfuron (Sol$\mathrm{ida}^{\mathrm{TM}}$ ) tank mixed with flumioxazin was the best treatment and provided 79\% and $77 \%$ control of dog fennel and common ragweed compared with all other treatments at 60 DAT (Table 2). Similarly, Hutchinson (2007) reported $90 \%$ or greater control of redroot pigweed, common lambsquarters, and green foxtail (Setaria viridis) with a tank mixture of rimsulfuron and flumioxazin in potato.

Rimsulfuron (Solida ${ }^{\text {TM }}$ ) tank mixed with oryzalin or pendimethalin did not improve weed control compared with rimsulfuron (Solida ${ }^{\mathrm{TM}}$ ) applied alone (Tables 1 and 2). Therefore, a selection of a tank mix partner should be made based on several factors including mode of action and weed control spectrum of herbicide, type of weeds, and weed density. Hutchinson (2007) reported that when redroot pigweed or common lambsquarters are the predominant weed species in a potato field, a tank mixture of rimsulfuron plus metribuzin may provide satisfactory weed control and addition of a third herbicide such as pendimethalin would not benefit. There was an overall reduction in weed control $(\leq 73 \%)$ at 90

Table 1. Efficacy of rimsulfuron applied alone or in tank mix with flumioxazin, pendimethalin, or oryzalin on broadleaf weed control at 15 and $30 \mathrm{~d}$ after treatment (DAT) in Expt. 1.

\begin{tabular}{|c|c|c|c|c|c|c|c|c|}
\hline \multirow[b]{2}{*}{ Herbicide treatment $^{\mathrm{z}}$} & \multicolumn{4}{|c|}{15 DAT $(\% \text { control })^{y}$} & \multicolumn{4}{|c|}{30 DAT $(\% \text { control })^{\mathrm{y}}$} \\
\hline & $\begin{array}{l}\text { Brazil } \\
\text { pusley }\end{array}$ & $\begin{array}{c}\text { Dog } \\
\text { fennel }\end{array}$ & $\begin{array}{c}\text { Common } \\
\text { ragweed }\end{array}$ & $\begin{array}{c}\text { Virginia } \\
\text { pepperweed }\end{array}$ & $\begin{array}{l}\text { Brazil } \\
\text { pusley }\end{array}$ & $\begin{array}{c}\text { Dog } \\
\text { fennel }\end{array}$ & $\begin{array}{c}\text { Common } \\
\text { ragweed }\end{array}$ & $\begin{array}{c}\text { Virginia } \\
\text { pepperweed }\end{array}$ \\
\hline Untreated control & $0 \mathrm{~b}$ & $0 \mathrm{~b}$ & $0 \mathrm{~b}$ & $0 \mathrm{~b}$ & $0 \mathrm{~b}$ & $0 \mathrm{c}$ & $0 \mathrm{~b}$ & $0 \mathrm{~b}$ \\
\hline $\begin{array}{l}\text { Rimsulfuron } \\
\qquad\left(\text { Solida }^{\mathrm{TM}}\right) 1 \mathrm{oz} / \text { acre }\end{array}$ & $97 \mathrm{a}$ & $97 \mathrm{a}$ & 97 a & 98 a & 83 a & $83 \mathrm{~b}$ & $83 \mathrm{a}$ & $84 \mathrm{~b}$ \\
\hline $\begin{array}{l}\text { Rimsulfuron } \\
\left.\text { (Matrix }{ }^{\circledR} \mathrm{FNV}\right) 1 \mathrm{oz} / \text { acre }\end{array}$ & $97 \mathrm{a}$ & $98 \mathrm{a}$ & $96 \mathrm{a}$ & 98 a & $83 \mathrm{a}$ & $85 \mathrm{ab}$ & $83 \mathrm{a}$ & $87 \mathrm{ab}$ \\
\hline $\begin{array}{l}\text { Rimsulfuron }\left(\text { Solida }^{\mathrm{TM}}\right) 1 \mathrm{oz} / \mathrm{acre}+ \\
\text { pendimethalin } 1 \mathrm{lb} / \text { acre }\end{array}$ & 97 a & 98 a & 97 a & 97 a & $84 \mathrm{a}$ & $84 \mathrm{ab}$ & $82 \mathrm{a}$ & $83 \mathrm{~b}$ \\
\hline $\begin{array}{l}\text { Rimsulfuron } \\
\left(\text { Solida }^{\mathrm{TM}}\right) 1 \mathrm{oz} / \text { acre }+ \\
\text { flumioxazin } 0.255 \mathrm{lb} / \text { acre }\end{array}$ & 99 a & $99 \mathrm{a}$ & 99 a & 99 a & 89 a & $91 \mathrm{a}$ & 88 a & $94 \mathrm{a}$ \\
\hline
\end{tabular}

${ }^{2}$ All herbicide treatments were included nonionic surfactant (Induce ${ }^{\circledR} ;$ Helena Chemical Co., Collierville, TN) at 0.25\% v/v; Matrix® FNV (E.I. Du Pont de Nemours and Co., Wilmington, DE), Solida ${ }^{\mathrm{TM}}$ (Cheminova, Research Triangle Park, NC); l oz/acre $=0.0701 \mathrm{~kg} \cdot \mathrm{ha}{ }^{-1}, 1 \mathrm{lb} / \mathrm{acre}=1.1209 \mathrm{~kg} \cdot \mathrm{ha}{ }^{-1}$.

${ }^{y}$ Data were arcsine transformed for homogenous variance before analysis; however, data presented are the means of actual values for comparison. Means within columns with no common letters are significantly different according to Fisher's protected least significant difference test where $P<0.05$.

Table 2. Efficacy of rimsulfuron applied alone or in tank mix with flumioxazin, pendimethalin, or oryzalin on broadleaf weed control at 60 and $90 \mathrm{~d}$ after treatment (DAT) in Expt. 1.

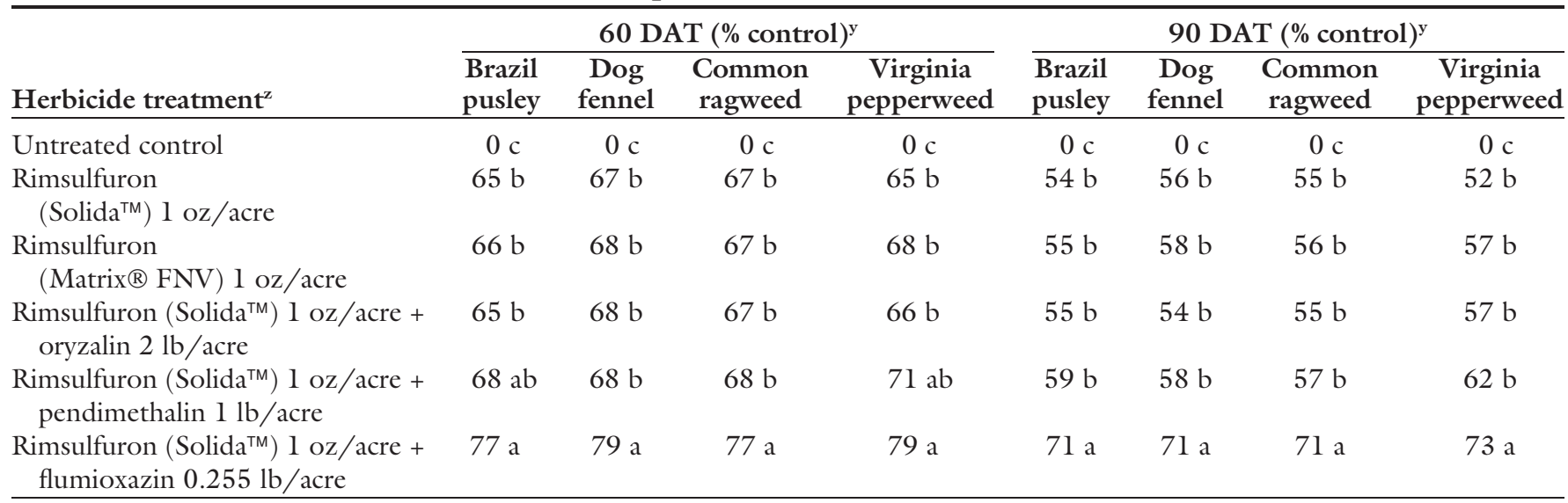

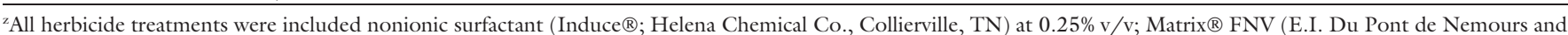

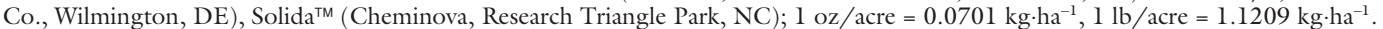

y Data were arcsine transformed for homogenous variance before analysis; however, data presented are the means of actual values for comparison. Means within columns with no common letters are significantly different according to Fisher's protected least significant difference test where $P<0.05$. 
DAT (Table 2). A tank mix of rimsulfuron (Solida ${ }^{\mathrm{TM}}$ ) with flumioxazin was the best treatment with $\approx 70 \%$ control of all weeds, even at 90 DAT, compared with other tank mix treatments and rimsulfuron (Solida ${ }^{\mathrm{TM}}$ ) applied alone (Table 2). This might be because rimsulfuron and flumioxazin are broad-spectrum herbicides and both have residual activity that resulted in the highest weed control. Since flumioxazin has different mode of action, a previous study reported that a tank mixing flumioxazin with pendimethalin provided control of ALS-resistant and triazine-resistant weeds in annual crops (Taylor-Lovell et al., 2002).

There was no injury on citrus trees in any herbicide treatment suggesting rimsulfuron (Solida ${ }^{\mathrm{TM}}$ or $\mathrm{Ma}$ trix ${ }^{\circledR}$ FNV) applied alone or in tank mixtures were safe to use in citrus (data not shown). All herbicides were applied as per the label direction; therefore, excellent crop safety was expected. A study reported that potato cultivars resulted in slight injury ( $2 \%$ to $8 \%)$ of rimsulfuron with no reduction in yield, but injuries were increased (14\% to $20 \%$ ) when rimsulfuron was applied with metribuzin (Ivany, 2002).

Experiment 2. The most common broadleaf weeds infesting experimental site in Haines City (2010) and Winter Garden (2011) were brazil pusley, virginia pepperweed, and cotton weed. A common grass weed infesting the experimental sites was natalgrass. Compared with the untreated control, all herbicide treatments provided $>86 \%$ control of all weed species at 15 and 30 DAT with some difference among herbicide treatments (Table 3). For example, rimsulfuron (Solida ${ }^{\mathrm{TM}}$ ) plus flumioxazin provided better weed control compared with rimsulfuron (Sol$\mathrm{ida}^{\mathrm{TM}}$ ) applied alone at $30 \mathrm{DAT}$ with usually no difference among tank mix treatments. Later in the season, tank mixing rimsulfuron (Solida ${ }^{\mathrm{TM}}$ ) and flumioxazin resulted in $\geq 97 \%$ and $\geq 79 \%$ control of all weed species at 60 and 90 DAT, respectively (Table 4). Compared with Expt. 1, better weed control was observed beyond 30 DAT in Expt. 2. This might be because of some residual activity of previous herbicide treatments sprayed in April. A sequential application of herbicides is a common weed control practice in perennial crops including citrus and it is necessary to achieve acceptable weed control throughout the year (Altland et al., 2003; Elmore et al., 1997).

There was a reduction in residual activity of herbicides at 90 DAT. Rimsulfuron (Solida ${ }^{\mathrm{TM}}$ ) applied alone was usually as effective as rimsulfuron (Matrix ${ }^{\circledR}$ FNV) for weed control (Tables 3 and 4). Among tank mix partners, flumioxazin was the most effective compared with oryzalin or pendimethalin and resulted in effective broadleaf weed control in both the experiments. However, all tank mix treatments were equally effective for control of natalgrass. This was because pendimethalin and oryzalin are primarily grass active herbicides with limited activity on small-seeded dicot weeds (Altland et al., 2003; BASF Corp., 2009). In this study, most of the weeds present were broadleaf species, and therefore pendimethalin or oryzalin were not as effective as a tank mix partner with rimsulfuron (Solida ${ }^{\mathrm{TM}}$ ), compared with flumioxazin which can control grass and broadleaf weeds (Valent USA, 2005 ). Flumioxazin has been an excellent tank mix partner with other herbicides. Richardson and Zandstra (2006) reported $96 \%$ and $77 \%$ control of yellow nutsedge with a tank mix of flumioxazin with S-metalochlor or oryzalin, respectively.

Overall results of this study suggest that rimsulfuron is an additional herbicide for chemical weed control in citrus because of its control of certain grass and broadleaf weeds. Additionally, it has both preemergence and postemergence activity, so it can control existing weeds as well as provide limited residual activity. In this study, tank mixing rimsulfuron (Solida ${ }^{\mathrm{TM}}$ ) with pendimethalin or oryzalin has not provided extended residual activity compared with rimsulfuron (Solida ${ }^{\text {TM }}$ ) applied alone; however, flumioxazin provided $>70 \%$ weed control in the first application and $>80 \%$ control at 90 DAT in a sequential application. Brazil pusley and cotton weed are among the problem weeds in citrus and ability of

Table 3. Efficacy of rimsulfuron applied alone or in tank mix with flumioxazin, pendimethalin, or oryzalin on weed control at 15 and $30 \mathrm{~d}$ after treatment (DAT) in Expt. 2.

\begin{tabular}{|c|c|c|c|c|c|c|c|c|}
\hline \multirow[b]{2}{*}{ Herbicide treatment ${ }^{\mathrm{z}}$} & \multicolumn{4}{|c|}{15 DAT $(\% \text { control })^{y}$} & \multicolumn{4}{|c|}{30 DAT (\% control $)^{\mathrm{y}}$} \\
\hline & $\begin{array}{l}\text { Brazil } \\
\text { pusley }\end{array}$ & $\begin{array}{c}\text { Virginia } \\
\text { pepperweed }\end{array}$ & $\begin{array}{c}\text { Cotton } \\
\text { weed }\end{array}$ & Natalgrass & $\begin{array}{l}\text { Brazil } \\
\text { pusley }\end{array}$ & $\begin{array}{c}\text { Virginia } \\
\text { pepperweed }\end{array}$ & $\begin{array}{c}\text { Cotton } \\
\text { weed }\end{array}$ & Natalgrass \\
\hline Untreated control & $0 \mathrm{~d}$ & $0 \mathrm{c}$ & $0 \mathrm{c}$ & $0 \mathrm{~d}$ & $0 \mathrm{~d}$ & $0 \mathrm{~d}$ & $0 \mathrm{c}$ & $0 \mathrm{~d}$ \\
\hline $\begin{array}{l}\text { Rimsulfuron } \\
\qquad\left(\text { Solida }^{\mathrm{TM}}\right) 1 \mathrm{oz} / \text { acre }\end{array}$ & $87 \mathrm{c}$ & $87 \mathrm{~b}$ & $89 \mathrm{~b}$ & $88 \mathrm{c}$ & $86 \mathrm{c}$ & $89 \mathrm{c}$ & $89 \mathrm{~b}$ & $88 \mathrm{c}$ \\
\hline $\begin{array}{l}\text { Rimsulfuron } \\
\left.\text { (Matrix }{ }^{\circledR} \mathrm{FNV}\right) 1 \mathrm{oz} / \text { acre }\end{array}$ & $94 \mathrm{bc}$ & $94 \mathrm{~b}$ & $95 \mathrm{ab}$ & $93 \mathrm{bc}$ & $93 \mathrm{bc}$ & $91 \mathrm{bc}$ & $93 \mathrm{~b}$ & $87 \mathrm{c}$ \\
\hline $\begin{array}{l}\text { Rimsulfuron }\left(\text { Solida }{ }^{\mathrm{TM}}\right) \mathrm{l} \mathrm{oz} / \mathrm{acre}+ \\
\text { pendimethalin } 1 \mathrm{lb} / \text { acre }\end{array}$ & $96 \mathrm{ab}$ & $96 \mathrm{ab}$ & $97 \mathrm{ab}$ & $97 \mathrm{ab}$ & $96 \mathrm{ab}$ & $96 \mathrm{ab}$ & $96 \mathrm{ab}$ & $97 \mathrm{ab}$ \\
\hline $\begin{array}{l}\text { Rimsulfuron }\left(\text { Solida }^{\mathrm{TM}}\right) \mathrm{l} \mathrm{oz} / \mathrm{acre}+ \\
\text { flumioxazin } 0.255 \mathrm{lb} / \text { acre }\end{array}$ & 99 a & 99 a & 99 a & 99 a & 99 a & 99 a & 99 a & 99 a \\
\hline
\end{tabular}

${ }^{2}$ All herbicide treatments were included nonionic surfactant (Induce ${ }^{\circledR}$; Helena Chemical Co., Collierville, TN) at 0.25\% v/v; Matrix ${ }^{\circledR}$ FNV (E.I. Du Pont de Nemours and Co., Wilmington, DE), Solida ${ }^{\mathrm{TM}}$ (Cheminova, Research Triangle Park, NC); $1 \mathrm{oz} / \mathrm{acre}=0.0701 \mathrm{~kg} \cdot \mathrm{ha}^{-1}, \mathrm{llb} / \mathrm{acre}=1.1209 \mathrm{~kg} \cdot \mathrm{ha}{ }^{-1}$.

'Data were arcsine transformed for homogenous variance before analysis; however, data presented are the means of actual values for comparison. Means within columns with no common letters are significantly different according to Fisher's protected least significant difference test where $P<0.05$. 
Table 4. Efficacy of rimsulfuron applied alone or in tank mix with flumioxazin, pendimethalin, or oryzalin on weed control at 60 and $90 \mathrm{~d}$ after treatment (DAT) in Expt. 2.

\begin{tabular}{|c|c|c|c|c|c|c|c|c|}
\hline \multirow[b]{2}{*}{ Herbicide treatment ${ }^{\mathrm{z}}$} & \multicolumn{4}{|c|}{60 DAT $(\% \text { control })^{\mathrm{y}}$} & \multicolumn{4}{|c|}{90 DAT $(\% \text { control })^{\mathrm{y}}$} \\
\hline & $\begin{array}{l}\text { Brazil } \\
\text { pusley }\end{array}$ & $\begin{array}{c}\text { Virginia } \\
\text { pepperweed }\end{array}$ & $\begin{array}{c}\text { Cotton } \\
\text { weed }\end{array}$ & Natalgrass & $\begin{array}{l}\text { Brazil } \\
\text { pusley }\end{array}$ & $\begin{array}{c}\text { Virginia } \\
\text { pepperweed }\end{array}$ & $\begin{array}{c}\text { Cotton } \\
\text { weed }\end{array}$ & Natalgrass \\
\hline Untreated control & $0 \mathrm{~d}$ & $0 \mathrm{~d}$ & $0 \mathrm{c}$ & $0 \mathrm{c}$ & $0 \mathrm{~d}$ & $0 \mathrm{c}$ & $0 \mathrm{e}$ & $0 \mathrm{c}$ \\
\hline $\begin{array}{l}\text { Rimsulfuron } \\
\qquad\left(\text { Solida }^{\mathrm{TM}}\right) 1 \mathrm{oz} / \text { acre }\end{array}$ & $78 \mathrm{bc}$ & $85 \mathrm{bc}$ & $89 \mathrm{ab}$ & $74 \mathrm{~b}$ & $60 \mathrm{c}$ & $57 \mathrm{~b}$ & $57 \mathrm{~d}$ & $58 \mathrm{ab}$ \\
\hline $\begin{array}{l}\text { Rimsulfuron } \\
\quad\left(\text { Matrix }{ }^{\circledR} \mathrm{FNV}\right) 1 \mathrm{oz} / \text { acre }\end{array}$ & $68 c$ & $74 \mathrm{c}$ & $84 \mathrm{~b}$ & $68 \mathrm{~b}$ & $58 \mathrm{c}$ & $57 \mathrm{~b}$ & $60 \mathrm{~cd}$ & $41 \mathrm{~b}$ \\
\hline $\begin{array}{l}\text { Rimsulfuron }\left(\text { Solida }{ }^{\mathrm{TM}}\right) 1 \mathrm{oz} / \text { acre }+ \\
\text { pendimethalin } 1 \mathrm{lb} / \text { acre }\end{array}$ & $84 \mathrm{~b}$ & $89 \mathrm{~b}$ & $91 \mathrm{ab}$ & $77 \mathrm{~b}$ & $69 \mathrm{~b}$ & $69 \mathrm{~b}$ & $70 \mathrm{~b}$ & $69 \mathrm{a}$ \\
\hline $\begin{array}{l}\text { Rimsulfuron }\left(\text { Solida }^{\mathrm{TM}}\right) \mathrm{l} \mathrm{oz} / \text { acre }+ \\
\text { flumioxazin } 0.255 \mathrm{lb} / \text { acre }\end{array}$ & 98 a & 98 a & 98 a & $97 \mathrm{a}$ & $83 \mathrm{a}$ & $83 \mathrm{a}$ & $81 \mathrm{a}$ & 79 a \\
\hline
\end{tabular}

rimsulfuron (Solida ${ }^{\mathrm{TM}}$ ) plus flumioxazin to control these weeds will provide an additional advantage to citrus growers upon registration of flumioxazin. In this study, there was no phytotoxic effect of any herbicide treatment on citrus trees in any year, indicating rimsulfuron (Solida) and tank mixes were safe to use in citrus when applied as per the label direction and under normal weather conditions.

\section{Conclusion}

This research was conducted to compare weed control efficacy of rimsulfuron (Solida ${ }^{\mathrm{TM}}$ ) applied alone or in tank mix with flumioxazin, pendimethalin or oryzalin in Florida citrus. Rimsulfuron (Solida ${ }^{\mathrm{TM}}$ ) applied alone provided $>80 \%$ weed control early in the season up to 30 DAT, but control was reduced beyond this time. Therefore, it is important to tank mix rimsulfuron with herbicide that can provide longer residual weed control. Pendimethalin or oryzalin were not much effective tank mix partners with rimsulfuron (Solida ${ }^{\mathrm{TM}}$ ) in this study. Tank mixing rimsulfuron (Solida ${ }^{\mathrm{TM}}$ ) with flumioxazin was the most effective compared with other treatments. More research is required to understand interaction of rimsulfuron with recently registered herbicides in citrus including saflufenacil and indaziflam to know if tank mixing of these herbicides with rimsulfuron has antagonistic, synergistic, or additive effects on weeds.

\section{Literature cited}

Altland, J.E., C.H. Gilliam, and G. Wehtje. 2003. Weed control in field nurseries. HortTechnology 13:9-14.

Askew, S.D., J.W. Wilcut, and J.R. Cranmer. 1999. Weed management in peanut (Arachis hypogaea) with flumioxazin preemergence. Weed Technol. 13:594598.

B.A.S.F. Corp. 2009. Prowl $\mathrm{H}_{2} \mathrm{O}^{\mathrm{TM}}$ herbicide label. BASF Corp., Research Triangle Park, NC.

Burke, I.C., S.D. Askew, and J.W. Wilcut. 2002. Flumioxazin systems for weed management in North Carolina peanut (Arachis hypogeae). Weed Technol. 16: 743-748.

Cheminova. 2010. Solida ${ }^{\mathrm{TM}}$ herbicide label. Cheminova Inc., Research Triangle Park, NC.

Dayan, F.E. and S.O. Duke. 1997. Phytotoxicity of protoporphyrinogen oxidase inhibitors: Phenomenology, mode of action and mechanisms of resistance, $\mathrm{p} .11-$ 36. In: R.M. Roa, J.D. Burton, and R.J. Kuhr (eds.). Herbicide activity: Toxicology, biochemistry and molecular biology. ISO Press, Burke, VA.

Eberlein, C.V., J.C. Whitmore, C.E. Stanger, and M.J. Guttieri. 1994. Postemergence weed control in potatoes (Solanum tuberosum) with rimsulfuron. Weed Technol. 8:425-428.

Elmore, C.L., I. Merwin, and D. Cudney. 1997. Weed management in tree fruit, nuts, citrus and vine crops, p. 17-29. In: M.E. McGuffen (ed.). Weed management in horticultural crops. ASHS Press, Alexandria, VA.
Futch, S.H. and M. Singh. 2012. Weeds, p. 123-133. In: M.E. Rogers, M.M. Dewdney, and T.M. Spann (eds.). 2012 Florida citrus pest management guide. Univ. of Florida, Coop. Ext. Serv., Inst. Food Agr. Sci. SP-43.

Green, J.M. and J.H. Green. 1993. Surfactant structure and concentration strongly affect rimsulfuron activity. Weed Technol. 7:633-640.

Hutchinson, P.J.S. 2007. A comparison of flumioxazin and rimsulfuron tank mixtures for weed control in potato. Weed Technol. 21:1023-1028.

Hutchinson, P.J.S., R.A. Boydston, C.V. Ransom, D.J. Tonks, and B.R. Beutler. 2005. Potato variety tolerance to flumioxazin and sulfentrazone. Weed Technol. 19:683-696.

Ivany, J.A. 2002. Control of quickgrass (Elytrigia repens) and broadleaf weeds and response of potato (Solanum tuberosum) cultivars to rimsulfuron. Weed Technol. 16:261-266.

Jhala, A.J. and B.D. Hanson. 2011. Summer weed control with glyphosate tank mixed with indaziflam or penoxsulam in California orchards and vineyards. Proc. 51 st Annu. Conf. Weed Sci. Soc. Amer. Portland, OR. p. 21. (Abstr.).

Kelly, S.T., M.W. Shankle, and D.K. Miller. 2006. Efficacy and tolerance of flumioxazin on sweetpotato (Ipomoea batata). Weed Technol. 20:334-339.

Richardson, R.J. and B.H. Zandstra. 2006. Evaluation of flumioxazin and other herbicides for weed control in gladiolus. Weed Technol. 20:394-398.

Schneiders, G.E., M.K. Koeppe, M.V. Naidu, P. Horne, M. Brown, and C.F. 
Mucha. 1993. Fate of rimsulfuron in the environment. J. Agr. Food Chem. 41:2404-2410.

Senseman, S.E. (ed.). 2007. Rimsulfuron, p. 109-111. In: Herbicide handbook. 9th ed. Weed Sci. Soc. Amer., Lawrence, KS.

Sharma, S.D. and M. Singh. 2007. Effect of timing and rates of application of glyphosate and carfentrazone herbicides and their mixtures on the control of some broadleaf weeds. HortScience 42:12211226.

Singh, M., M.S. Malik, A.H.M. Ramirez, and A.J. Jhala. 2011. Tank mix of saflufenacil with glyphosate and pendimethalin for broad-spectrum weed control in Florida citrus. HortTechnology 21:606-615.
Singh, S. and M. Singh. 2004. Effect of growth stage on trifloxysulfuron and glyphosate efficacy in twelve weed species of citrus groves. Weed Technol. 18:10311036.

Taylor-Lowell, S., L.M. Wax, and G. Bollero. 2002. Preemergence flumioxazin and pendimethalin and postemergence herbicide systems for soybean (Glycine max). Weed Technol. 16:502-511.

Tonks, D.J. and C.V. Eberlein. 2001. Postemergence weed control with rimsulfuron and various adjuvants in potato (Solanum tuberosum). Weed Technol. 15:613-616.

U.S. Department of Agriculture. 2010. Citrus: 2009-2010 Citrus summary: Production, practices and value. 5 May 2012.
<http://www.nass.usda.gov/Statistics by_State/Florida/Publications/Citrus/ cspre/cit92310.pdf>.

U.S. Department of Agriculture. 2012. Florida citrus statistics 2010-2011. 14 May 2012. <http://www.nass.usda.gov/ Statistics_by_State/Florida/Publications / Citrus/fcs/2009-10/fcs0910.pdf>.

Valent U.S.A. 2005. Chateau WDG herbicide product label. Valent USA Corp., Walnut Creek, CA.

Wilson, D.E., S.J. Nissen, and A. Thompson. 2002. Potato (Solanum tuberosum) variety and weed response to sulfentrazone and flumioxazin. Weed Technol. 16:567574 . 